\title{
Pelagic and benthic trophic chain coupling in a semi-enclosed coastal system, the Bay of Brest (France): a modelling approach
}

\author{
O. Le Pape ${ }^{1, *}$, F. Jean ${ }^{2}$, A. Ménesguen ${ }^{3}$ \\ ${ }^{1}$ IFREMER-RH, Avenue du Général de Gaulle, 14520 Port en Bessin, France \\ ${ }^{2}$ UMR 6539, Ecologie benthique, IUEM, Place Nicolas Capesnic, 29280 Plouzané, France \\ ${ }^{3}$ IFREMER-DEL, BP 70, 29280 Plouzané, France
}

\begin{abstract}
During the 2 last decades several studies have analysed the response of phytoplankton dynamics and benthic trophic webs to increasing anthropogenic eutrophic conditions in the Bay of Brest, France. The present project couples 2 models, a pelagic and a benthic one, to synthesise both these approaches to this ecosystem. This model shows that in spite of net carbon production being more than 10-fold lower than phytoplankton production benthic suspension feeders partly control the phytoplankton dynamics in the Bay. Computation of the nitrogen fluxes reveals the role of the benthic trophic chain in nutrient recycling. It is possible to show that an increase in nitrogen loading in the Bay would have limited consequences on the ecosystem, with the excess nitrogen being transferred to shelf waters without entering the trophic chain. The problem of toxic bloom events that can affect benthic suspension feeders, and consequently the total ecosystem, will have to be thoroughly studied.
\end{abstract}

KEY WORDS: Eutrophication - Dynamic simulation model - Bay of Brest - Hydrodynamism - Phytoplankton Benthos

\section{INTRODUCTION}

The main problem in studies of phytoplankton dynamics in coastal shallow ecosystems (CSEs; review in Cloern 1996) deals with the complex interactions between the host of factors that influence biological productivity. According to Mallin et al. (1993) and to Cloern $(1982,1996)$, climate, seasonality, physical forcing, nutrient loading and recycling and benthic grazers interact in this regulation. To understand the dynamics of such an ecosystem and to prevent damage due to anthropogenic effects (Cloern 1996), and especially eutrophication (May 1973), it is necessary to couple physical and biological approaches and to take both the pelagic and benthic systems into account.

The Bay of Brest, France (Fig. 1), is a semi-enclosed coastal ecosystem where increasing nutrient loading

•E-mail: olepape@ifremer.fr from freshwater inputs predominates (Joanny et al. 1993). Several projects have studied this ecosystem, especially to estimate the risks of eutrophication damage with nitrogen enrichment.

A physical model was developed by Salomon \& Breton (1991). Biogeochemical cycles of limiting nutrients and phytoplankton dynamics have been studied for 20 yr (Delmas et al. 1983, Quẻguiner \& Tréguer 1984, Hafsaoui et al. 1985, Ragueneau et al. 1994, Le Pape et al. 1996) and a physical-biological coupled model of this pelagic system has recently been developed (Le Pape \& Ménesguen 1997). This model shows that in spite of huge nutrient loading, the Bay of Brest seems to be protected from eutrophication. When benthic suspension feeders were simulated as a black box in this pelagic model, these feeders were involved in grazing control of phytoplankton dynamics.

The benthic system has also been a topic of surveys since the early 1980s. Hily (1991) studied the biomasses and filtration rates of benthic suspension feed- 


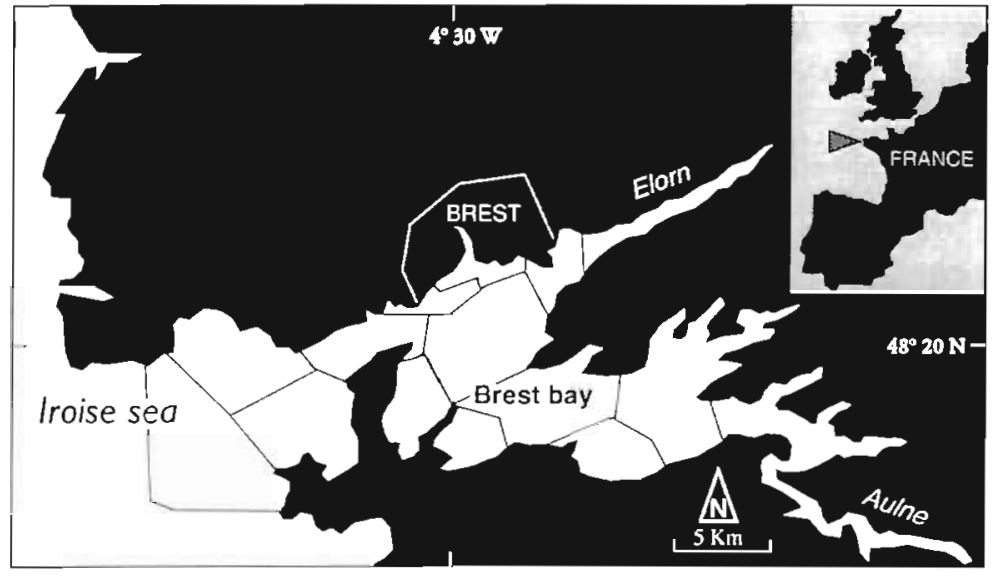

Fig. 1. General location of the site under study and geographical boxes of the model

ers in the Bay of Brest. He computed that $30 \%$ of the water of the Bay is filtered every day and concluded that benthic feeders seem to control phytoplankton stocks. Conversely, from the benthic steady state model developed by Jean \& Thouzeau (1995), benthic suspension feeders' net carbon production rate per year is only equal to $5 \%$ of the phytoplankton production and this does not seem to be important enough to control phytoplankton blooms.

From 3 different approaches, opposite conclusions have been reached concerning the key point: Does the benthos control phytoplankton blooms in the Bay of Brest?

The purpose of this work is to couple the benthic model with the dynamic pelagic one to obtain a synthetic physical-biological model of the Bay of Brest ecosystem. First this model is used to describe the role of benthic suspension feeders in the control of phytoplankton. It also provides an estimation of the nitrogen fluxes for the entire ecosystem and the role of increasing nitrogen loading.

\section{MATERIAL AND METHODS}

Physical model. The physical basis of this model is the same as the first pelagic model (Le Pape \& Ménesguen 1997). We developed this model using 'ELISE' software (Ménesguen 1991). This software allows us to subdivide the system into 15 boxes coinciding with the different gyres of the long-term drift trajectories (Salomon \& Breton 1991). Water advective-diffusive fluxes between these boxes and with the shelf waters of the Iroise Sea (Fig. 1) are computed from the results of the physical model (Salomon \& Breton 1991). This model takes into account the river flow and simu- lates a 2-layer vertical thermohaline structure for each of the 15 boxes (Hoch \& Ménesguen 1996).

Thanks to 'ELISE' software, it is possible to add a biological model to this physical structure

Biological variables. As explained in Le Pape et al. (1996), 2 nutrients (N, Si) limit primary production in the Bay of Brest. As in the first pelagic model (Le Pape \& Ménesguen 1997), biogeochemical cycles of nitrogen and silicon are simulated in both pelagic and benthic layers. Two phytoplankton groups are taken into account: diatoms, which are the only living compartment of the model that includes silicon, and dinoflagellates. Zooplankton biomass is simulated, and the benthic trophic layer is simplified into 4 variables (meiofauna, deposit feeders + herbivorous, benthic suspension feeders, carnivorous + fishes). Furthermore, because recently dead diatoms are consumed as living ones by suspension feeders (Jean 1994), they have been distinguished from detrital matter. In all, 17 variables are simulated (Table 1), diatoms being the only compartment involved in the 2 biogeochemical cycles. Conversion parameters between the different units are given in Table 2. The conceptual diagram (Fig. 2) shows the relationships between variables.

Table 1. State variables of the biological model

\begin{tabular}{|c|c|c|}
\hline Abbrev. & State variable & Unit \\
\hline DIN & Pelagic dissolved inorganic nitrogen & $\mu \mathrm{mol} \mathrm{l}^{-1} \mathrm{~N}$ \\
\hline DetN & $\begin{array}{l}\text { Pelagic detrital organic nitrogen } \\
\text { (except dead diatoms) }\end{array}$ & $\mu \mathrm{mol} \mathrm{l} \mathrm{l}^{-1} \mathrm{~N}$ \\
\hline $\mathrm{BDIN}$ & Benthic DIN & $\mathrm{mmolm} \sim \mathrm{N}$ \\
\hline BDetN & $\begin{array}{l}\text { Benthic detrital. organic nitrogen } \\
\text { (except dead diatoms) }\end{array}$ & $\mathrm{mmol} \mathrm{m} \mathrm{m}^{-2} \mathrm{~N}$ \\
\hline $\mathrm{Si}(\mathrm{OH}) 4$ & Pelagic silicic acid & $\mu \mathrm{mol} \mathrm{l}^{-1} \mathrm{Si}$ \\
\hline DetSi & Pelagic biogenic detrital silica & $\mu \mathrm{mol} \mathrm{l}{ }^{-1} \mathrm{Si}$ \\
\hline $\mathrm{BSi}(\mathrm{OH}) 4$ & Benthic silicic acid & $\mathrm{mmol} \mathrm{m}^{2} \mathrm{Si}$ \\
\hline BDetSi & Benthic biogenic detrital silica & $\mathrm{mmol} \mathrm{m} \mathrm{mi}^{-2} \mathrm{Si}$ \\
\hline Dia & Diatoms & $\mu \mathrm{gl}^{-1} \mathrm{chl} a$ \\
\hline Dino & Dinollagellates & $\mu g l^{-1} \operatorname{chl} a$ \\
\hline Zoo & Zooplankton & $\mu g l^{-1}$ dry wt \\
\hline DeaDia & Nitrogen of pelagic dead diatoms & $\mu \mathrm{mol} \mathrm{1}{ }^{-1} N$ \\
\hline BDeaDia & Nitrogen of benthic dead diatoms & $\mathrm{mmol} \mathrm{m}^{-2} \mathrm{~N}$ \\
\hline Meio & Meiofauna & $g m^{-2} \mathrm{C}$ \\
\hline $\mathrm{DH}$ & Deposit feeders + herbivorous & $g \mathrm{~m}^{-2} \mathrm{C}$ \\
\hline Su & Benthic suspension feeders & $g \mathrm{~m}^{-2} \mathrm{C}$ \\
\hline$C P$ & Carnivorous + fishes & $\mathrm{g} \mathrm{m}^{-2} \mathrm{C}$ \\
\hline
\end{tabular}


Table 2. Conversion parameters between usual units used in the biological model

\begin{tabular}{|lccl|}
\hline Explanation & Unit & Value & Source \\
\hline Phytoplankton N/chl a ratio & $\mathrm{mol} \mathrm{g}^{-1}$ & 1 & Antia et al. (1963) \\
Phytoplankton C/Nratio & $\mathrm{mol} \mathrm{mol}^{-1}$ & 6.62 & Redfield (1934) \\
Diatom Si/N ratio & $\mathrm{mol} \mathrm{mol-1}^{-1}$ & 0.5 & Harrison et al. (1977) \\
C/Nratio for zooplankton and benthic fauna & $\mathrm{mol} \mathrm{mol}^{-1}$ & 5 & Anderson (1992) \\
Zooplankton C/dry weight ratio & $\mathrm{g} \mathrm{g}^{-1}$ & 0.25 & Le Fèvre-Lehoerff et al. (1992) \\
\hline
\end{tabular}

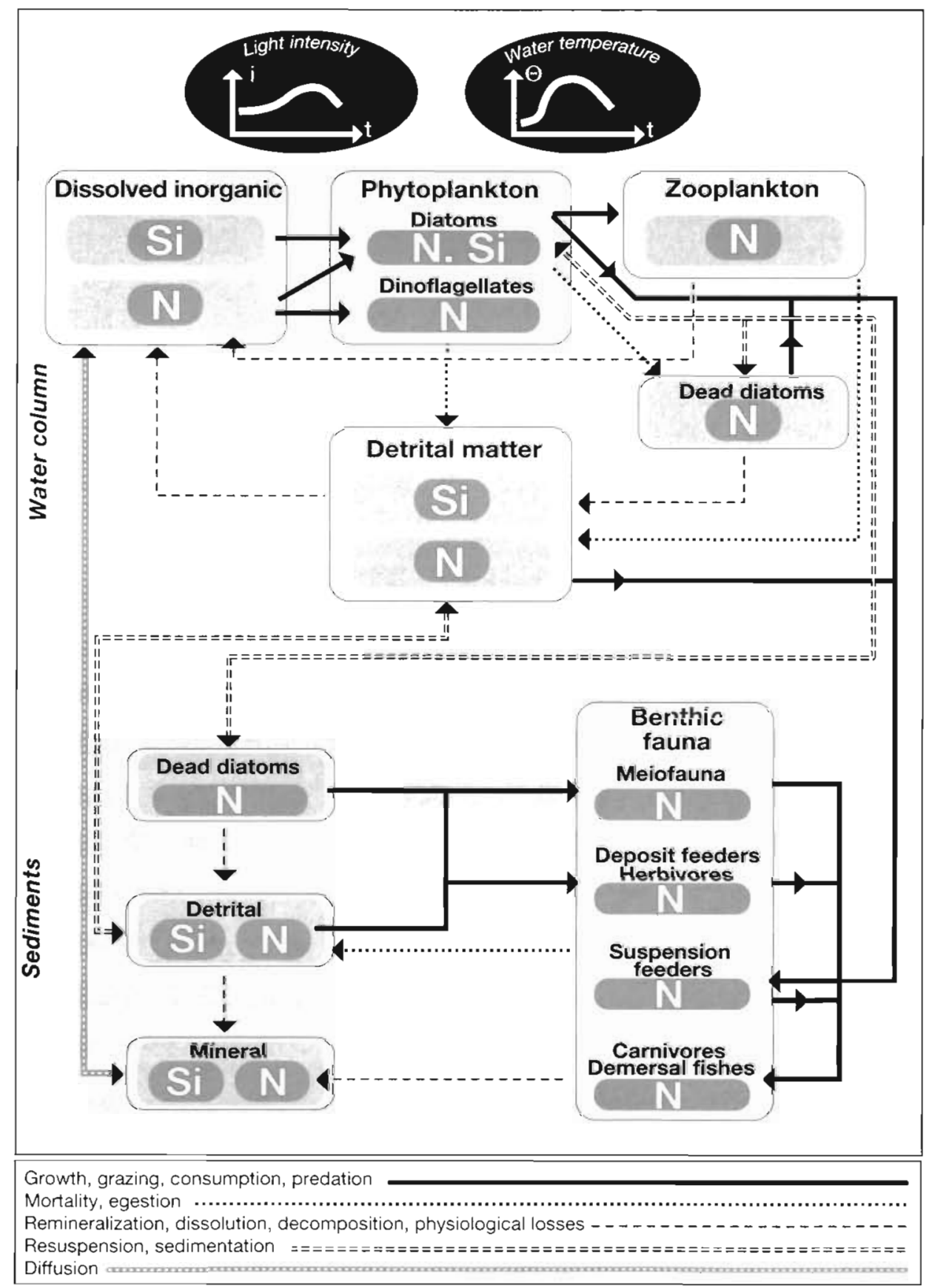

Fig. 2. Conceptual diagram of the biological model 
Processes. All of the state variables representing living matter can be described by the following equation:

$$
\frac{\mathrm{d} X_{1}}{\mathrm{~d} t}=\left(\mu_{1}-\eta_{i}-\rho_{i}\right) \times X_{1}-\sum_{j} C_{i j} \times X_{j}
$$

where $X_{i}=$ biomass of the living compartment $i_{i} \mu_{i}=i$ growth rate $\left(\mathrm{d}^{-1}\right) ; \eta_{i}=i$ mortality rate $\left(\mathrm{d}^{-1}\right) ; \rho_{i}=i$ physiological losses $\left(\mathrm{d}^{-1}\right) ; C_{i j}=$ consumption rate of $i$ by $j$ $\left(\mathrm{d}^{-1}\right)_{i}$ and $\mathrm{X}_{j}=$ predator $j$ biomass.

Phytoplankton: Phytoplankton growth rate $\mu \varphi\left(\mathrm{d}^{-1}\right)$ depends on water temperature, light, and nutrient concentration:

$$
\mu \varphi=\mu \max \varphi 0 \times f_{1}(T) \times \min \left[f_{2}(I), f_{3} \text { (Nutrients) }\right]
$$

where $\mu \max \varphi 0=$ potential growth rate at $0^{\circ} \mathrm{C}\left(\mathrm{d}^{-1}\right)$; $f_{1}(T)=$ temperature effect; $f_{2}(I)=$ light effect; and $f_{3}($ Nutrients $)=$ nutrient limitation

Temperature effect $f_{1}(T)$ is exponential [Eppley 1972: $f_{1}(T)=\exp (0.07 \times T)$, where $T=$ simulated temperature $\left.\left({ }^{\circ} \mathrm{C}\right)\right]$. This same equation is used for all of the temperature dependent processes in the model.

According to Steele (1962), the light-limiting effect on a water layer $\left(z_{\text {inf }}, z_{\text {sup }}\right)$ is:

$$
f_{2}(I)=\frac{1}{z_{\text {sup }}-z_{\text {inf }}} \times \int_{z_{\text {int }}}^{z_{\text {sup }}} \frac{I_{z} / 2}{I_{\text {opt }}} \times \exp \left(1-\frac{I_{2} / 2}{I_{\text {opt }}}\right) \mathrm{d} z
$$

where $I_{\mathrm{op}}=$ optimal light intensity $\left(\mathrm{W} \mathrm{m}^{-2}\right)$, and $I_{z}=$ light intensity $\left(\mathrm{W} \mathrm{m}^{-2}\right)$ at depth $z(\mathrm{~m})$ :

$$
I_{z}=I_{\text {surf }} \times \exp \left(-K_{1} \times 2\right)
$$

where $I_{\text {surt }}=$ surface light intensity $\left(\mathrm{W} \mathrm{m}^{-2}\right)$, and $K_{1}=$ light extinction coefficient $\left(\mathrm{m}^{-1}\right)$ computed with the Prieur \& Sathyendranath (1981) formula to take self shading into account:

$$
K_{\iota}=K_{\text {nc }}+0.04 \times(\text { Dia }+ \text { Dino })^{0.6}
$$

where $K_{n c}=$ non-chlorophyllous extinction coefficient $\left(\mathrm{m}^{-1}\right)$ computed for the different parts of the Bay on the annual cycle from the 1993 data (Le Pape et al. 1996) with the Prieur \& Sathyendranath (1981) inverted formula, and Dia + Dino = total chlorophyll a (chl a) concentration ( $\left.\mu \mathrm{g} \mathrm{l}^{-1}\right)$.

For each nutrient, the limiting function follows the Michaelis-Menten formula:

$$
f_{4}(D I N, D i a)=\frac{D I N}{D I N+k N(D i a)}
$$

(example of DIN limitation for diatoms)

where $k N(D i a)=$ diatom half saturation constant for DIN ( $\left.\mu \mathrm{mol} \mathrm{l}{ }^{-1}\right)$.

Dinoflagellates are DIN limited: $f_{3}($ Nutrients, Dino $)=$ $f_{4}(D I N$, Dino $)$. Diatom nutrient limitation is a conjunction of DIN and Si(OH)4 limitation (De Groot 1983, O' Neill et al. 1989): $f_{3}($ Nutrients, Dia $)=\frac{1}{\sqrt{\frac{1}{f_{4}\left(\mathrm{SiO}_{2}, \mathrm{Dia}\right)}+\frac{1}{f_{4}(\mathrm{DIN}, \mathrm{Dia})}-1}}$

Mortality of the 2 phytoplankton groups is temperature dependent. Physiological losses are neglected.

In the surface layer, diatoms have a constant sedimentation velocity. To take their resuspension into account, an empirical formula is used for the bottom layer for this sedimentation velocity (SVDia in $\mathrm{m} \mathrm{d}^{-1}$ ):

$$
\text { SVDia }=\max S V D i a \times \min \left(1, \frac{H}{l i m d e p}\right)
$$

where maxSVDia $=$ diatom sedimentation velocity without resuspension $\left(\mathrm{m} \mathrm{d}^{-1}\right), H=\operatorname{depth}(\mathrm{m})$, and limdep: maximum depth of sedimentation velocity limitation (30 m).

Zooplankton: Zooplankton growth rate $\left(\mu Z, \mathrm{~d}^{-1}\right)$ is dependent on temperature and diatom abundance. Dinoflagellate grazing is ignored (Ives 1987). Referring to Moloney \& Bergh (1986), diatom limitation follows a Michaelis-Menten formula with a predation slope:

$\mu Z=\mu \max Z 0 \times f_{1}(T) \times\left(\frac{\text { Dia }-P S D i a Z}{K D i a Z+(D i a-P S D i a Z)}\right) \times\left(1-\varepsilon_{z o 0}\right)$

where $\mu \max Z 0=$ zooplankton maximum growth rate at $0^{\circ} \mathrm{C}\left(\mathrm{d}^{-1}\right), K D i a Z=$ zooplankton half saturation for diatoms $\left(\mu \mathrm{g} \mathrm{chl} \mathrm{al}^{-1}\right), P S D i a Z=$ predation slope $(\mu \mathrm{g} \mathrm{chl} a$ $\left.\mathrm{l}^{-1}\right)$, and $\varepsilon_{z 00}=$ egestion rate, $\varepsilon_{z 00} \in[0,1]$.

Zooplankton mortality and physiological losses are temperature dependent. Mortality is also biomass dependent (Steele \& Henderson 1992), meaning that pelagic predation is considered to be proportional to zooplankton biomass:

$$
\eta_{z 00}=f_{1}(T) \times \max (\eta \min Z 0, \eta B D Z 0 \times Z o o)
$$

where $\eta \min Z 0=$ minimum mortality at $0^{\circ} \mathrm{C}\left(\mathrm{d}^{-1}\right)$, and $\eta B D Z 0=$ biomass dependent mortality at $0^{\circ} \mathrm{C}\left(\mathrm{d} \mu \mathrm{g} \mathrm{l}^{-1}\right)^{-1}$.

Benthic fauna: Growth rates of benthic fauna variables are temperature, food and density dependent. Consumption of prey $i$ by predator $j\left(\mu_{i j}\right.$ in $\left.\mathrm{d}^{-1}\right)$ is modelled as in Wiegert et al. (1981):

$$
\mu_{j j}=\tau_{j} \times f_{1}(T) \times \pi_{i j} \times f_{5 i j} \times f_{6 j j} \times\left(1-\varepsilon_{i j}\right)
$$

where $\tau_{j}=$ predator $j$ ingestion rate at $0^{\circ} \mathrm{C}\left(\mathrm{d}^{-1}\right), \pi_{i j}=$ affinity of predator $j$ for prey $i\left(\pi_{i j} \in[0,1\}_{i} \sum_{i} \pi_{i j}=1\right), f_{5 i j}=$ prey $i$ limitation, $f_{6 j j}=j$ density-dependent limitation, and $\varepsilon_{i j}=$ egestion rate, $\varepsilon_{i j} \in[0,1]$.

Prey limitation:

$$
f_{5 i j}=\max \left[0, \min \left(1, \frac{X_{i}-S \operatorname{Min}_{i}}{S M a x_{1 j}-S M i n_{i}}\right)\right]
$$

where $X_{i}=$ prey $i$ biomass, $S M_{i n}=$ minimum slope of predation rate for prey $i$ (prey unit), and $S M a x_{i j}=\max$ - 
imal slope of predation rate of predator $j$ for prey $i$ (prey unit).

Density-dependent factor:

$$
\begin{aligned}
f_{6 \mu}= & \max \left(\frac{\eta_{j}+\rho_{j}}{\tau_{j} \times\left(1-\varepsilon_{j}\right)^{\prime}}\right. \\
& \left.1-\left\{\left(1-\frac{\eta_{j}+\rho_{j}}{\tau_{j} \times\left(1-\varepsilon_{j}\right)}\right) \times\left[\min \left(1, \frac{X_{j}-\operatorname{SMin}_{j j}}{\operatorname{SMax}_{j j}-\operatorname{SMin}_{j j}}\right)\right]\right\}\right)
\end{aligned}
$$

where $\frac{\eta_{j}+p_{j}}{\tau_{j} \times\left(1-\varepsilon_{j}\right)}=$ basic energetic cost, $S M a x_{j j}=$ slope over which ingestion rate of $j$ reaches basic energy cost ( $\left.g \mathrm{C} \mathrm{m}^{-2}\right)$, SMin $_{j j}=$ slope under which there is no density-dependent limitation $\left(\mathrm{g} \mathrm{C} \mathrm{m}^{-2}\right), \varepsilon_{j}=$ average egestion rate of $j=\frac{\sum_{i}\left(f_{5 i j} \times \varepsilon_{i j}\right)}{\sum_{i} f_{5 i j} \times \sum_{i} \varepsilon_{l j}}$.

The global growth rate $\left(\mathrm{d}^{-1}\right)$ of a benthic compartment $j$ is

$$
\mu_{j}=\sum_{i} \mu_{i j}
$$

There is 1 exception to this rule: for benthic suspension feeders, living and recently dead diatoms are summed and considered as only 1 prey.
Physiological losses and mortality are temperature dependent for the benthic fauna.

Non-living variables: Remineralization of detrital matter $\left(\mathrm{d}^{-1}\right)$ is also temperature dependent, with lower rates in the benthic layer than in water (Table 3). Dead diatoms become detrital matter with a rate dependent on temperature. Sedimentation velocity and the resuspension rate of detrital matter and dead diatoms are constant. Diffusive fluxes of nutrients between water and sediment ( $\mu \mathrm{mol} \mathrm{l^{-1 }} \mathrm{d}^{-1}$ ) are also modelled (Van der Molen 1991):

$$
\text { Diff } N=\text { DINDiffR } \times \frac{\frac{B D I N}{\text { seddep }}-\text { DIN }}{\text { seddep }}
$$

where DINDiffR = diffusion rate of DIN in the benthic layer $\left(\mathrm{m} \mathrm{d}^{-1}\right)$, and seddep $=$ depth of the active benthic layer $(0.3 \mathrm{~m})$.

Tuning of the model. Meteorological conditions and

\begin{tabular}{|c|c|c|c|}
\hline Explanation & Unit & Value & Source \\
\hline \multicolumn{4}{|l|}{ Detrital organic matter } \\
\hline Pelagic detrital nitrogen mineralization rate at $0^{\circ} \mathrm{C}$ & $d^{-1}$ & 0.01 & Baretta-Becker et al. (1994) \\
\hline Pelagic biogenic silica dissolution at $0^{\circ} \mathrm{C}$ & $d^{-1}$ & 0.06 & Tuning \\
\hline Benthic detrital nitrogen mineralization rate at $0^{\circ} \mathrm{C}$ & $d^{-1}$ & 0.0004 & Tuning \\
\hline Benthic biogenic silica dissolution at $0^{\circ} \mathrm{C}$ & $d^{-1}$ & 0.002 & Tuning \\
\hline Diffusion rate of nitrogen & $m d^{-1}$ & 0.0001 & Van der Molen (1991) \\
\hline Diffusion rate of silicic acid & $\mathrm{m} \mathrm{d}^{-1}$ & 1 & Tuning \\
\hline Resuspension rate of detrital matter and dead diatoms & $\mathrm{d}^{-1}$ & 0.002 & Tuning \\
\hline Sedimentation velocity of detrital matter and dead diatoms & $\mathrm{m} \mathrm{d}^{-1}$ & 1.5 & Andersen \& Nival (1988) \\
\hline Rate from dead diatoms to detrital matter at $0^{\circ} \mathrm{C}$ & $d^{-1}$ & 0.02 & Tuning \\
\hline Slope for pelagic detrital nitrogen consumption & $\mu \mathrm{mol} \mathrm{N} \mathrm{l}^{-1}$ & 0.2 & Tuning \\
\hline Slope for benthic detrital nitrogen consumption & $\mathrm{g} \mathrm{N} \mathrm{m}^{-2}$ & 0.035 & Chardy \& Dauvin (1992) \\
\hline Slope for benthic dead diatoms consumption & $\mathrm{g} \mathrm{N} \mathrm{m} \mathrm{m}^{-2}$ & 0.035 & Chardy \& Dauvin (1992) \\
\hline \multicolumn{4}{|l|}{ Diatoms } \\
\hline Maximum growth rate at $0^{\circ} \mathrm{C}$ & $d^{-1}$ & 0.45 & Chapelle (1991) \\
\hline Optimal light intensity & $W m^{-2}$ & 100 & Andersen (1985) \\
\hline Half saturation for DIN & $\mu \mathrm{mol} \mathrm{l} \mathrm{l}^{-1}$ & 2 & Eppley (1972) \\
\hline Half saturation for $\mathrm{Si}(\mathrm{OH}) 4$ & umol $1^{-1}$ & 1 & Paasche (1973) \\
\hline Mortality rate at $0^{\circ} \mathrm{C}$ & $\mathrm{d}^{-1}$ & 0.02 & Andersen (1985) \\
\hline Sedimentation maximum velocity & $\mathrm{m} \mathrm{d}^{-1}$ & 1 & Fasham et al. (1990) \\
\hline Predation slope for zooplankton & $\mu g \operatorname{chl} a l^{-1}$ & 0.15 & Moloney \& Bergh (1986) \\
\hline Predation slope for benthic suspension feeders & $\mu \mathrm{g} c h l a l^{-1}$ & 0.25 & Tuning \\
\hline \multicolumn{4}{|l|}{ Dinoflagellates } \\
\hline Maximum growth rate at $0^{\circ} \mathrm{C}$ & $d^{-1}$ & 0.25 & Peterson \& Festa (1984) \\
\hline Optimal light intensity & $W \mathrm{~m}^{-2}$ & 180 & Andersen (1985) \\
\hline Half saturation for DIN & $\mu$ mol DIN l-1 & 3 & Tuning \\
\hline Mortality rate at $0^{\circ} \mathrm{C}$ & $\mathrm{d}^{1}$ & 0.05 & Radach \& Moll (1993) \\
\hline \multicolumn{4}{|l|}{ Zooplankton } \\
\hline Maximum growth rate at $0^{\circ} \mathrm{C}$ & $d^{-1}$ & 0.3 & Tuning \\
\hline Half saturation for chl a & $\mu \mathrm{gchl} a \mathrm{l}^{-1}$ & 0.7 & Steele \& Henderson (1992) \\
\hline Physiological losses at $0^{\circ} \mathrm{C}$ & $d^{-1}$ & 0.01 & Fasham et al. (1990) \\
\hline Egestion rate & Adimensional & 0.4 & Azam et al. (1983) \\
\hline Minimum mortality rate at $0^{\circ} \mathrm{C}$ & $d^{-1}$ & 0.06 & Steele \& Henderson (1992) \\
\hline Density-dependent mortality rate at $0^{\circ} \mathrm{C}$ & $d^{-1}\left(\mu g^{-1} l\right)$ & 0.0012 & Tuning \\
\hline
\end{tabular}
limit conditions (freshwater flows, nutrient concentrations in freshwater, values for the pelagic state variables in the shelf waters, initial conditions) are the

Table 3. Parameters of the biological model, except for benthic fauna 
Table 4. Predation slopes and physiological parameters for benthic fauna

\begin{tabular}{|c|c|c|c|c|}
\hline Explanation & Meiofauna & $\begin{array}{l}\text { Deposit feeders } \\
+ \text { herbivorous }\end{array}$ & $\begin{array}{l}\text { Suspension } \\
\text { feeders }\end{array}$ & $\begin{array}{l}\text { Carnivorous } \\
+ \text { fishes }\end{array}$ \\
\hline Maximum growth rate at $0^{\circ} \mathrm{C}\left(\mathrm{d}^{-1}\right)$ & 0.45 & 0.05 & 0.017 & 0.003 \\
\hline Mortality rate at $0^{\circ} \mathrm{C}\left(\mathrm{d}^{-1}\right)$ & 0.005 & 0.0018 & 0.001 & 0.0008 \\
\hline Physiological losses at $0^{\circ} \mathrm{C}\left(\mathrm{d}^{-1}\right)$ & 0.07 & 0.0075 & 0.003 & 0.0008 \\
\hline $\begin{array}{l}\text { Slope below which the ingestion rate is not } \\
\text { limited }\left(\mathrm{g} \mathrm{C} \mathrm{m}^{-2}\right)\end{array}$ & 0.8 & 2 & 5 & 2 \\
\hline $\begin{array}{l}\text { Slope above which energetic ingestion rate is } \\
\text { limited to the cost of constant stock maintenance }\left(\mathrm{g} \mathrm{C} \mathrm{m}^{-2}\right)\end{array}$ & 3 & 6.1 & 20 & 13 \\
\hline Predation slope $\left(\mathrm{g} \mathrm{C} \mathrm{m}^{-2}\right)$ & 0.2 & 0.2 & 0.6 & \\
\hline
\end{tabular}

same as in the pelagic model (Le Pape \& Ménesguen 1997) except for the benthic layer, whose initial conditions were taken from Jean (1994) and Jean \& Thouzeau (1995).

The model runs with a time step of $0.015 \mathrm{~d}(\sim 22 \mathrm{~min})$. Due to the non-linear relationships in the model and to uncertainty of initial conditions, simulations run with the values reached on December 31 as initial conditions for the next simulated year until a steady annual cycle was reached.

The year 1993 is used to tune the pelagic part of the model by comparing the results with the annual cycle data set (Le Pape et al. 1996, Del Amo et al. 1997). For the benthic part of the model, the tuning is based on 2 references: Jean \& Thouzeau (1995) measured winter biomasses of benthic fauna in the Bay of Brest but the entire annual cycle is unknown. Moreover a steady state model does not use all of the parameters necessary for a dynamic model. This is the reason why the tuning of the benthic part of the model is also based on the annual cycle of data and on the parameters given by Chardy \& Dauvin (1992) for the benthic trophic chain of another shallow nutrient-rich ecosystem located in the same region. Parameters values are given in Tables 3 to 8 .

\section{RESULTS}

\section{Tuning and validation of the model}

The physical structure is not changed from the pelagic model (Le Pape \& Ménesguen 1997). Simulated resident time (21 d, Salomon \& Breton 1991), water temperature and salinity are spatio-temporally well simulated. Nevertheless the vertical gradients of salinity observed in the upper layer during flow events cannot be reproduced with this 2 -layer vertical model.

Referring to Le Pape \& Ménesguen (1997), the pelagic part of the model, tuned on 1993 annual cycle data, is not strongly modified. This model gives acceptable discrepancies between measured and simulated data for the pelagic state variables, reproducing the annual cycle with several spring blooms, and silicic acid then DIN exhaustion (Fig. 3). The proportion of dinoflagellates and the zooplankton biomasses are also realistic. Moreover, the geographical gradients between the estuarine part of the Bay and the shelf waters are accurately reproduced. The same comparison applied to simulations based on 1977 data to validate the model shows that this model gives comparable discrepancies on a very different annual cycle. Nevertheless, there were no available data on phyto-

Table 5. Meiofauna feeding parameters

\begin{tabular}{|lll|}
\hline & BDetN & BDeaDia \\
\hline Trophic preferendum & 0.7 & 0.3 \\
Egestion & 0.75 & 0.75 \\
Slope of max. ingestion $\left(\mathrm{g} \mathrm{C} \mathrm{m}^{-2}\right)$ & 0.3 & 0.3 \\
\hline
\end{tabular}

Table 6. Deposit feeders + herbivorous feeding parameters

\begin{tabular}{|lcc|}
\hline & BDetN & BDeaDia \\
\hline Trophic preferendum & 0.65 & 0.35 \\
Egestion & 0.7 & 0.5 \\
Slope of max. ingestion $\left(\mathrm{g} \mathrm{C} \mathrm{m}^{-2}\right)$ & 0.3 & 0.3 \\
\hline
\end{tabular}

Table 7. Benthic suspension feeders feeding parameters

\begin{tabular}{|lcl|}
\hline & Dia + DeaDia & DetN \\
\hline Trophic preferendum & 0.85 & 0.15 \\
Egestion & 0.4 & 0.8 \\
Slope of max. ingestion $\left(\mathrm{g} \mathrm{C} \mathrm{m}^{-2}\right)$ & 1.6 & 1.6 \\
\hline
\end{tabular}

Table 8. Carnivorous + fishes feeding parameters

\begin{tabular}{llll}
\hline & Meio & DH & \multicolumn{1}{c}{ Su } \\
\hline Trophic preferendum & 0.15 & 0.25 & 0.6 \\
Egestion & 0.25 & 0.25 & 0.25 \\
Slope of max. ingestion $(\mathrm{g} C \mathrm{~m}$ & 1.5 & 1.5 & 7 \\
\hline
\end{tabular}



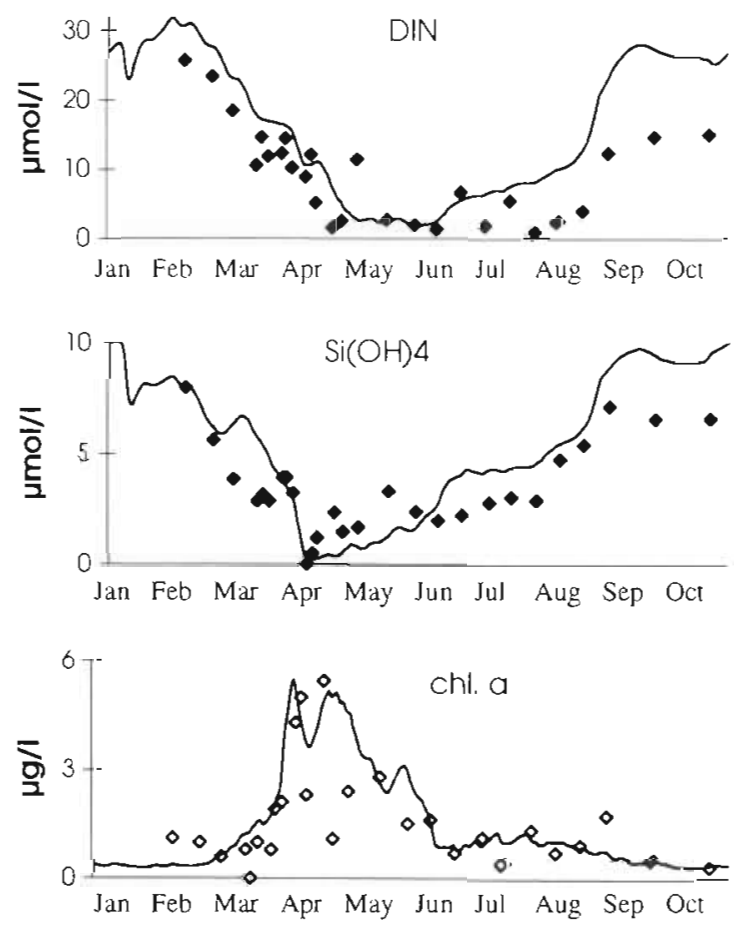

Fig. 3. Time series of measured $(\bullet, \diamond)$ and simulated $(-)$ bottom DIN, silicic acid and chlorophyll a concentrations for the year 1993 in the central part of the Bay of Brest

plankton composition for the 1977 annual cycle, or for other years, and so it is not possible to validate the proportion of dinoflagellates simulated

There are no available data to calibrate the simulations for benthic fauna on an entire annual cycle. Referring to Jean \& Thouzeau (1995), winter values appear realistic, although carnivorous macrofauna plus fish biomasses are overestimated (Fig. 4). These results compare well with data obtained on an annual cycle in the Bay of Morlaix, another nutrient-rich ecosystem in the same region (Chardy \& Dauvin 1992). The fast development of meiofauna in spring followed by a slower increase of deposit feeder, herbivorous and benthic suspension feeder biomasses in summer and then the increase of carnivorous and fishes are similar to results obtained here. The rates of annual variation in biomass are also similar to this study. Nonetheless, because variations in sediment granulometry are not taken into account, the geographical variations in benthic fauna (Hily 1991, Jean \& Thouzeau 1995) are strongly attenuated in these simulations.

\section{Sensitivity analysis}

Due to the physical forcing, the pelagic part of the model is insensitive to initial conditions. This is not the
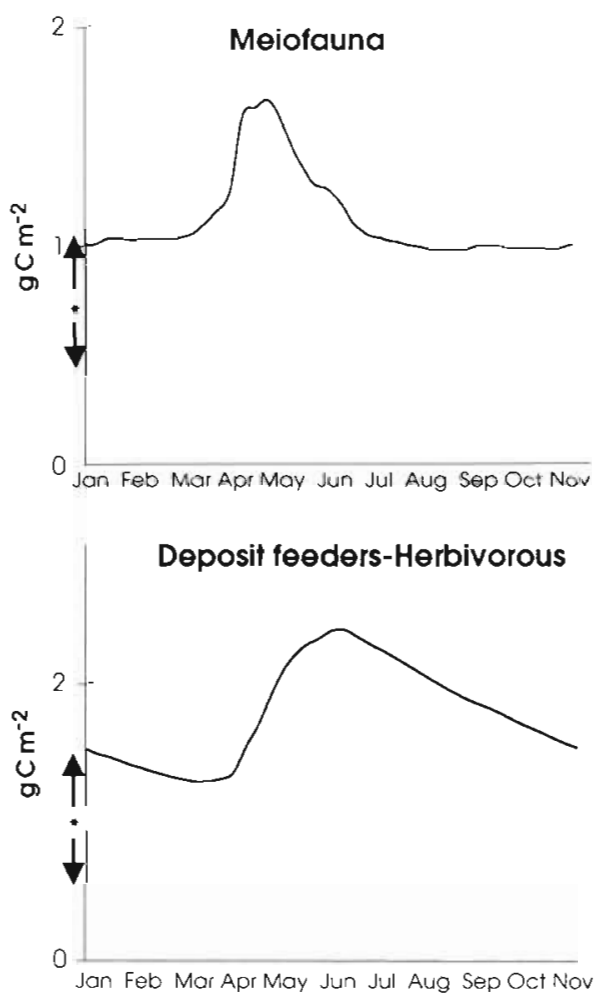

Benthic suspension feeders
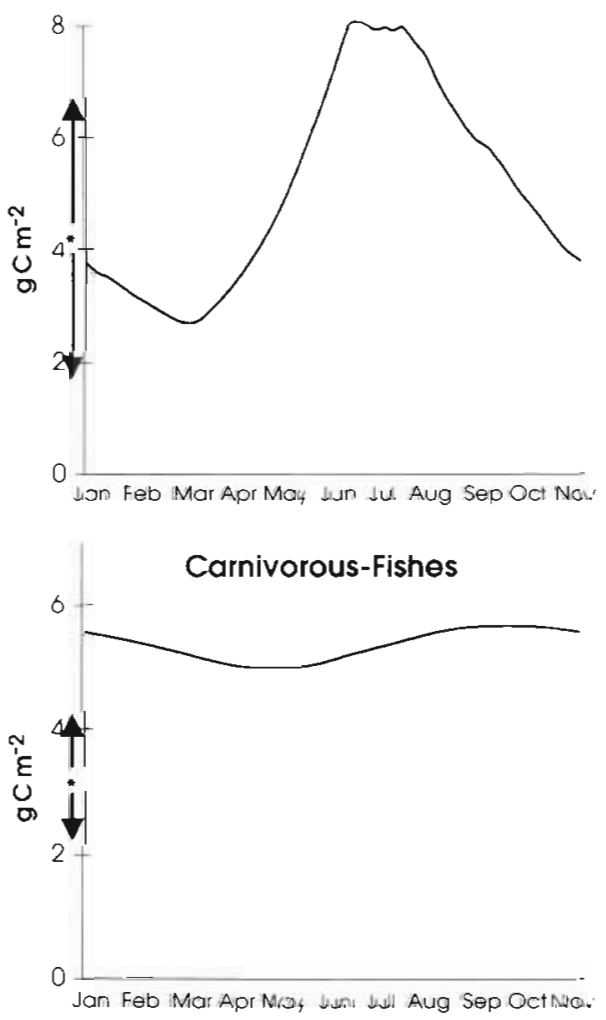

Fig. 4. Time series of simulated benthic fauna for the year 1993 in the central part of the Bay of Brest (winter measured biomasses and their standard errors are given on the vertical axis) 


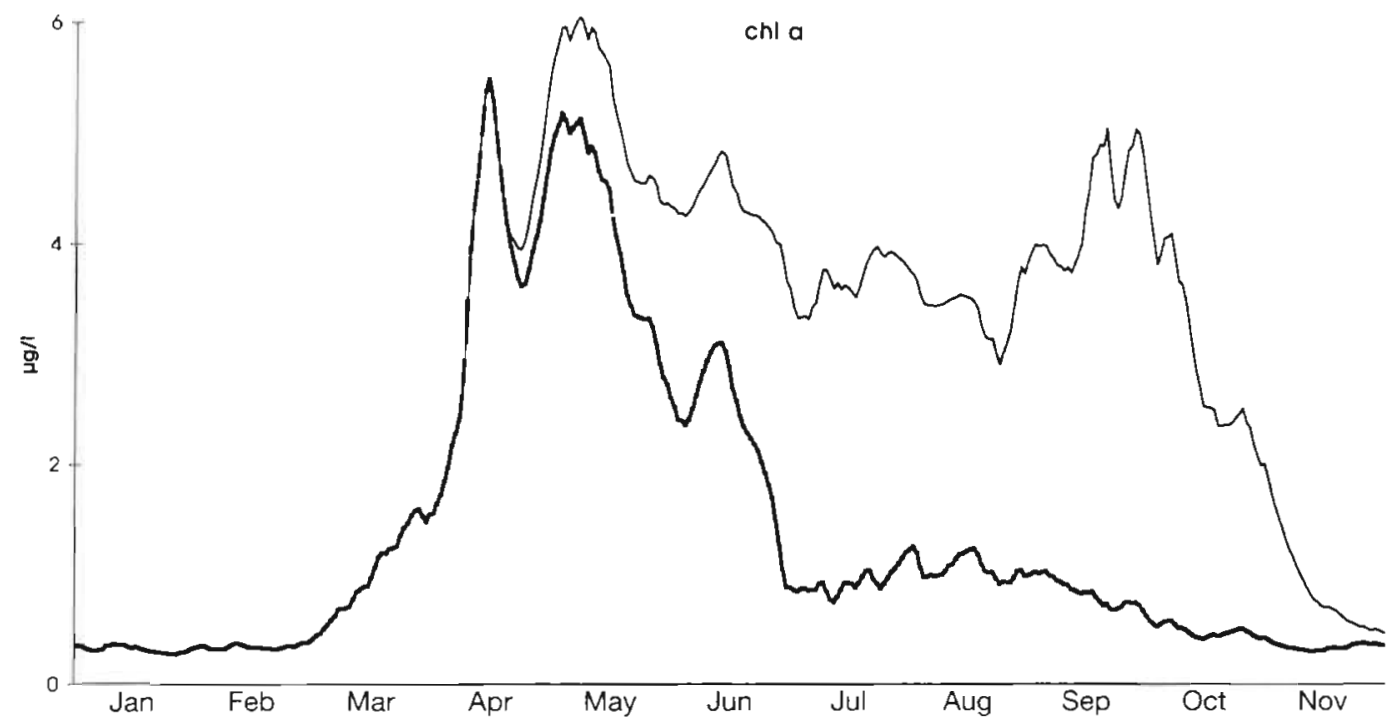

Fig. 5. Chlorophyll a concentration in the middle part of the Bay of Brest in 1993 with (-) and without $(-)$ simulated benthic grazing

case for the benthic fauna, but if realistic initial conditions are used, these conditions influence only the number of cycles of annual simulations before a steady simulated annual cycle is obtained, and so the results are not affected. The sensitivity of the model to parameters is not more important: simulations performed to test this sensitivity show that the resulting variation rate of simulated variables is less important than the fixed $(10 \%)$ variation rate of the parameters.

\section{Role of suspension feeders}

To study the role of benthos in phytoplankton dynamic control, a reference simulation is run until reaching a steady 1993 annual cycle and then filtration of benthic feeders is stopped during the productive period. Without benthic filtration, successive phytoplankton blooms (Fig. 5) occur between April and October, chl a concentration always being short of $6 \mu \mathrm{g}$ $\mathrm{l}^{-1}$, and nutrient concentrations are lower than in the reference simulation for this whole period. Annual maximum chl a values are fewly changed when benthic grazing is suppressed.

\section{Nitrogen fluxes in the system}

Nitrogen fluxes into and out of the whole ecosystem are calculated using the 1993 annual cycle (Fig. 6).

As calculated by Jean (1994), benthic suspension feeders' net production represents only a low percentage of primary production (5\% from Jean (1994); $7 \%$ from this model). Both biomasses and fluxes of these benthic feeders are hence realistic.
In relation to the shelf water exchanges, DIN freshwater loadings are 6 times lower. Due to these hydrodynamic exchanges, high nitrogen loading occurring during the winter period are evacuated to the shelf waters before the productive period. Phytoplankton exchanges are nearly equal to phytoplankton uptake proving that hydrodynamic exchanges mainly influence nitrogen biogeochemical cycles.

The diagram of these fluxes (Fig. 6) also shows that the biogeochemical cycle of nitrogen is highly driven by pelago-bentho exchanges. On 1 annual cycle: (1) more than $6000 \mathrm{t}$ of DIN are taken up by phytoplankton, (2) $7000 \mathrm{t}$ of phytoplanktonic and detrital organic nitrogen are transferred to the benthic layer through sedimentation and suspension-feeder filtration, and (3) these $7000 \mathrm{t}$ are mineralized by benthic fauna and transferred to the pelagic layer through DIN diffusion.

Compared with the pelagic loop (800 t), benthic recycling is the main recycling route and the nitrogen cycle can be summed up by 4 processes (Fig. 7).

\section{Response to increased nitrogen loading}

Hypothetical simulations were run with doubled freshwater nitrogen loading in 1977 and 1993. These simulations show the low response of nitrogen fluxes to these doubled nitrogen loadings (Fig. 8). Most of the nitrogen freshwater loading excess is transferred to the shelf waters without entering the nitrogen biogeochemical cycle. In relation to such an enrichment, the rate of increase of phytoplankton nitrogen uptake is only $14 \%$, the average rate of increase of biogeochemical fluxes in the ecosystem being $8 \%$. The rate of 


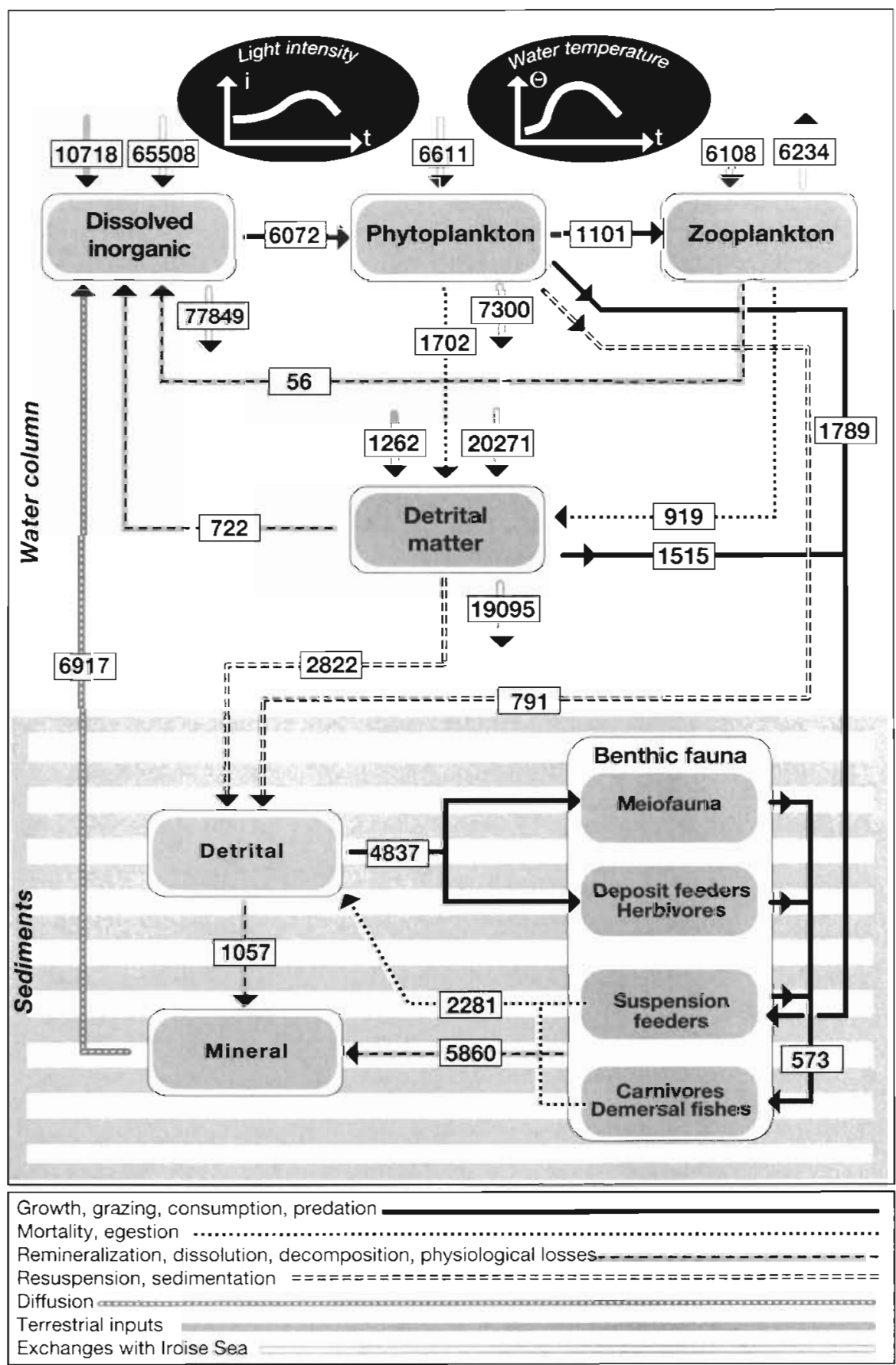

Fig. 6. Nitrogen fluxes (metric tons) in the Bay of Brest ecosystem in 1993

increase of biomass of living variables is also weak for such an enrichment ( $8 \%$ for phytoplankton stocks, $2.5 \%$ for benthic fauna).

As in Le Pape \& Ménesguen (1997), these simulations show that there is a high variability in the increase in the proportion of dinoflagellates in response to nitrogen enrichment. Increases in this proportion are $1 \%$ in 1977 and $33 \%$ in 1993

\section{DISCUSSION}

The pelagic part of this model is tuned on 1993 annual cycle field data and validated on 1977 data, except for dinoflagellate proportions, for which data are only available from 1993. As in Le Pape \& Ménesguen (1997), simulations reproduce these 2 different annual cycles quite well. 
There are no available data for the benthic fauna to calibrate a whole annual cycle in the Bay of Brest. Winter biomasses in this Bay (Jean \& Thouzeau 1995) and a comparison with the benthos annual cycle of another ecosystem in the same region (Chardy \& Dauvin 1992) were used for tuning. Simulations of the benthic fauna can also be considered as realistic even if spatial variations of simulated benthic biomasses are underestimated because the biosedimentary features and variability of benthic community composition are not taken into account (Jean \& Thouzeau 1995).

\section{Benthos control of phytoplankton dynamics}

This synthetic model enables us to understand the contrasting conclusions reached concerning the benthic influence on phytoplankton stocks in earlier studies. According to Hily (1991), the filtration rate of benthic suspension feeders is important enough for these feeders to control phytoplankton stocks. Nevertheless, fluxes computed by Jean (1994) show that the net production of benthic suspension feeders is less than 10\% of primary production. This synthetic model, which reproduces biomasses, fluxes and filtration rates computed in previous studies, demonstrates that, although production is low compared with phytoplankton studies, the benthos controls phytoplankton stocks. Comparable control has been obtained in mesocosm experiments by O'Viatt et al. (1993), Peeters et al. (1993) and Smaal et al. (1994), and through in situ studies in San Francisco Bay by Cloern (1982), in Narragansett Bay by Doering (1989) and in the Baltic Sea by Rosenberg (1991)

This model shows that annual net production does not seem to be a useful factor for estimating the possible control of a consumer on lower trophic levels.

\section{Consequences of nutrient enrichment}

From the model results, both living compartment biomasses and nitrogen fluxes between these compartments are little affected by nitrogen enrichment, as most of the nitrogen excess is transferred without entering the trophic chain. These new results on nitrogen fluxes confirm what has already been shown on biomasses in the pelagic layer (Le Pape \& Ménesguen 1997). Moreover, this model shows that nitrogen excess is not transferred in organic form to the benthic layer and that benthic fauna and fluxes are not affected by this enrichment.

Previous field studies confirm the Bay of Brest model result, suggesting that $94 \%$ of DIN freshwater loading reaches the Bay between October and March (Monbet

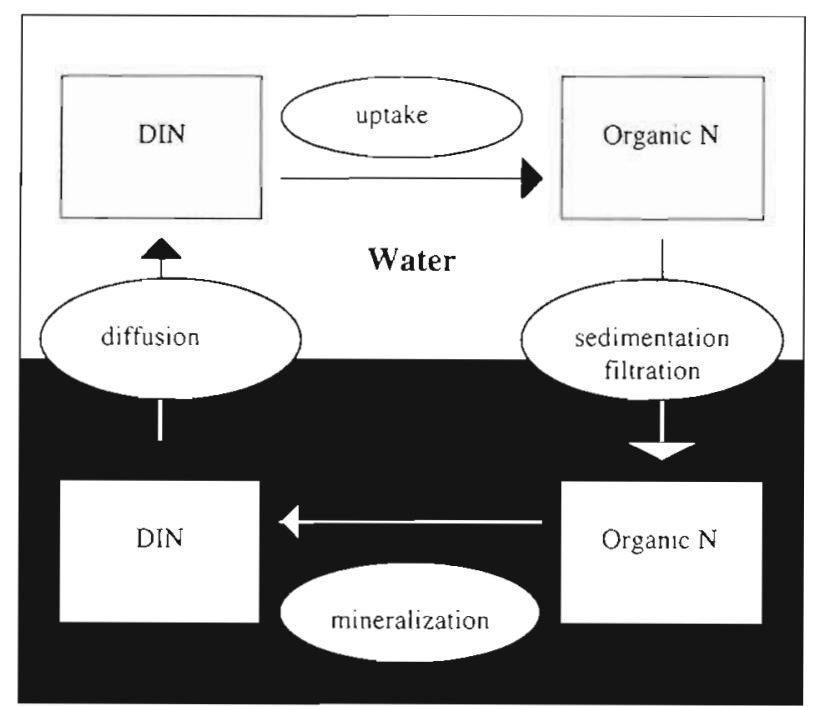

Fig. 7. Simplified nitrogen fluxes in the ecosystem

\& Bassoullet 1989). During this period climatic conditions strongly limit primary production (Le Pape et al. 1996) and hydrodynamic exchanges are important enough to drain freshwater nutrient loading off the Bay, When favourable conditions for primary production occur, these nitrogen stocks are not available for primary production. As in the German Bight (Hickel et al. 1993), in several fjords of Great Britain (Ross et al. 1994) and in San Francisco Bay (Cloern \& Jassby 1995) hydrodynamic properties have an important influence on eutrophication processes. Moreover, as proved by Lehman (1980) in a temperate lake, phytoplankton dynamics are controlled by abiotic factors in winter (climate and hydrodynamism) and trophic relationships influence increases in summer (benthic and also zooplankton grazing). Both hydrodynamics and the benthos strongly influence the consequences of nitrogen enrichment in the Bay of Brest.

The proportion of dinoflagellates in the model increases with nitrogen enrichment and is highly dependent on the annual cycle. Even if it has not been possible to validate the relative composition of the simulated phytoplankton community - field data were not available - this result indicates that the occurrence of toxic blooms during summer under specific climatic conditions may be a problem.

Coloured tides have already been observed in the Bay of Brest and several studies have shown the consequences of changes in the nutrient ratio on phytoplankton (Smayda 1990, Colijn 1992, Conley et al. 1993). When toxic blooms occur, benthic suspension feeders are affected (for review, see Shumway 1990); thus, one of the main controlling factors of phytoplankton stocks is temporally suppressed and secondary blooms may occur 


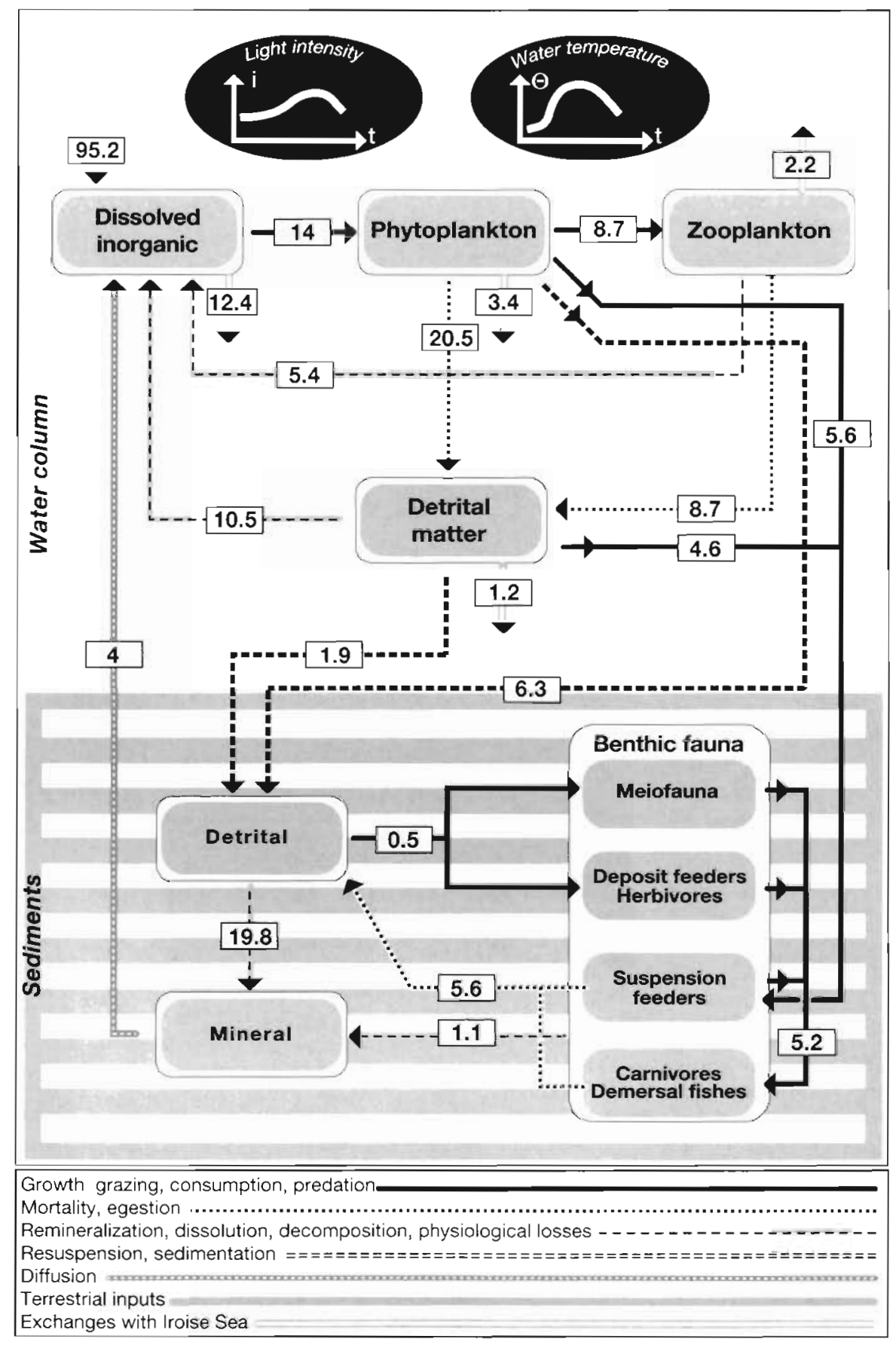

Fig. 8. Response of nitrogen fluxes (\%) in 1993, for doubled nitrogen freshwater loadings (Loadings increase equal $95.2 \%$ and not $100 \%$ because waste water plant fluxes stay unchanged)

This scenario needs to be studied with field data in order to be verified, as this part of the results cannot be considered to be sufficiently reliable. Dinoflagellate grazing is neglected, the role of suspension feeders in the cycle of silica by ingesting and deteriorating diatoms is modelled simply, vertical structure which highly influences flagellate blooms (Vilicic et al. 1989) is simulated approximately with a 2-layered vertical model and validation data are unavailable. Moreover, the scenario described in the last paragraph would lead to important changes in the ecosystem and the model structure is inadequate to describe such a situation. Recent field studies in the Bay of Brest confirm that there are complex interactions between phyto- 
plankton dynamics and benthic feeder grazing (Chauvaud et al. in press).

This model allows us to prove that even if such events were to occur in the Bay of Brest chl a concentrations would not reach the high levels measured in a highly eutrophicated Bay. Due to hydrodynamic exchange, the maximum phytoplankton stocks will not be greater than those now observed during spring blooms, as phytoplankton is transferred to nutrientpoor shelf waters.

Acknowledgements. Support for this research was provided by the 'Contrat de Baie' project on the Bay of Brest managed by 'the Communauté Urbaine de Brest'. We would like to thank Pierre Bodenes (IFREMER-DEL) for the conceptual diagram of the model, Charlie Cooper and Stuart Rogers (CEFAS) for their advice about writing English and the 3 anonymous reviewers for their helpful comments.

\section{LITERATURE CITED}

Andersen V (1985) Modélisation d'écosystèmes pélagiques Etude de processus. Thesis, Univ Pierre et Marie Curie, Paris

Andersen V, Nival P (1988) A pelagic ecosystem model, simulating production and sedimentation of biogenic particles: role of salps and copepods. Mar Ecol Prog Ser 44:37-50

Anderson TR (1992) Modelling the influence of food C:N ratio and respiration on growth and nitrogen excretion in marine zooplankton and bacteria. J Plankton Res 14(12):1645-1671

Antia AJ, MacAllister RCD, Parsons TR, Stephens K, Strickland DH (1963) Further measurments of primary production using a large-volume plastic sphere. Limnol Oceanogr 8:166-183

Azam F, Fenchel T, Field JG, Gray JS, Meyer Reil LA, Thingstad F (1983) The ecological role of water column microbes in the sea. Mar Ecol Prog Ser 10:257-263

Baretta-Becker JG, Riemann B, Baretta JW, Koch-Rasmussen $E$ (1994) Testing the microbial loop concept by comparing mesocosm data with results from a dynamical simulation model. Mar Ecol Prog Ser 106:187-198

Chapelle A (1991) Modélisaton d'un écosystème marin côtier soumis à l'eutrophisation: la baie de Vilaine. Etude du phytoplancton et du bilan en oxygène. Thesis, Univ Paris VI

Chardy P, Dauvin JC (1992) Carbon flows in a subtidal fine sand community from the western English Channel: a simulation analysis. Mar Ecol Prog Ser 81:147-161

Chauvaud L, Jean F, Thouzeau G, Ragueneau $R$ (in press) Long-term variation of the Bay of Brest ecosystem: benthic-pelagic coupling revisited. Mar Ecol Prog Ser

Cloern JE (1982) Does the benthos control phytoplankton biomass in south San Francisco Bay? Mar Ecol Prog Ser 9: 191-202

Cloern JE (1996) Phytoplankton bloom dynamics in coastal ecosystems: a review with some general lessons from sustained investigation of San Francisco Bay, California. Rev Geophys 34(2):127-168

Cloern JE, Jassby AD (1995) Year to year fluctuation of the spring phytoplankton bloom in South San Francisco Bay: an example of ecological variability at the land-sea interface. In: Steele JH, Powell TM, Levin S (eds) Ecological time series. Chapman and Hall. New York, p 139-149
Colijn F (1992) Changes in plankton communities: when, where and why? ICES Mar Sci Symp 195:193-212

Conley DJ, Schelske CL, Stoermer EF (1993) Modification of the biogeochemical cycle of silica with eutrophication. Mar Ecol Prog Ser 101:179-192

De Groot WT (1983) Modelling the multiple nutrient limitation of algal growth. Ecol Model 18:99-119

Del Amo Y, Le Pape O. Tréguer P, Quéguiner B, Ménesguen A, Aminot A (1997) Impacts of high-nitrate freshwater inputs on macrotidal ecosystems. I. Seasonal evolution of nutrient limitation for the diatom-dominated phytoplankton of the Bay of Brest (France). Mar Ecol Prog Ser 161:213-224

Delmas R, Hafsaoui M. Le Jehan S, Quéguiner B, Tréguer P (1983) Impact de fertilisations à forte variabilité saisonnière et annuelle sur le phytoplancton d'un écosystème eutrophe. Oceanol Acta out of series 81-85

Doering PH (1989) On the contribution of the benthos to pelagic production. J Mar Res 47(2):371-383

Eppley RW (1972) Temperature and phytoplankton growth in the sea. Fish Bull 70:1063-1085

Fasham MJR, Ducklow HW, McKelvies SM (1990) A nitrogen based model of plankton dynamics in the oceanic mixed layer. J Mar Res 48:591-639

Hafsaoui M, Quéguiner B, Tréguer P (1985) Production primaire et facteurs limitant la croissance du phytoplancton en rade de Brest. Oceanis 11:181-195

Harrisson PJ, Conway HL, Dugdale RC (1977) Marine diatoms grown in chemostats under silicate or ammonium limitation. III. Cellular chemical composition and morphology of Chaetoceros debilis, Skeletonema costatum and Thalassiosira gravida. Mar Biol 35:177-186

Hickel W, Mangelsdorf P, Berg J (1993) The human impact in the German bight: eutrophication during three decades (1962-1991). Helgol Meeresunters 47:243-263

Hily $C(1991)$ Is the activity of benthic suspension feeders a factor controling water quality in the Bay of Brest? Mar Ecol Prog Ser 69:179-188

Hoch T, Ménesguen A (1996) Modelling the biogeochemical cycles of elements limiting the primary production in the English Channel (N, P, Si). II. Sensitivity analyses. Mar Ecol Prog Ser 146:189-205

Ives JD (1987) Possible mechanisms underlying copepods grazing response to levels of toxicity in red tides dinoflagellates. J Exp Mar Biol Ecol 112(2):131-145

Jean F (1994) Modélisation à l'état stable des transferts de carbone dans le réseau trophique benthique de la rade de Brest (France). Thesis, Univ Bretagne Occidentale, Brest

Jean F. Thouzeau G (1995) Estimation des variables d'état d'un modèle de réseau trophique benthique en rade de Brest. C Acad Sci Sér III 318:145-154

Joanny $M$, Belin C, Claisse D, Miossec L, Berthome JP Grouhel A, Raffin B (1993) Qualité du milieu marin littoral IFREMER, Plouzané

Le Fèvre-Lehoerff G, Erard-Le Denn E, Arzul G (1992) Planktonic ecosystems in the Channel. Trophic relations. Oceanol Acta 16(5-6):661-670

Lehman JT (1980) Physical and chemical factors affecting the seasonnal abundance of Asterionella formasa hass in a small temperate lake. Arch Hydrobiol 87(3):274-303

Le Pape O, Ménesguen A (1997) Hydrodynamic prevention of eutrophication in the Bay of Brest (France). A modelling approach. J Mar Syst 12:171-186

Le Pape O, Del Amo Y, Ménesguen A, Aminot A, Quéguiner $B$, Tréguer P (1996) Resistance of a coastal ecosystem to increasing eutrophic conditions: the Bay of Brest (France), a semi-enclosed zone of western Europe. Cont Shelf Res 16(15):1885-1907 
Mallin MA, Paerl HW, Rudek J, Bates PW (1993) Regulation of estuarine primary production by watershed rainfall and river flow. Mar Ecol Prog Ser 93:199-203

May EB (1973) Extensive oxygen depletion in Mobile Bay, Alabama. Limnol Oceanogr 18:353-366

Ménesguen A (1991) 'ELISE', an interactive sof tware for modelling complex aquatic ecosystems. In: Arcilla AS, Pastor $M$, Zienkiewicz OC, Schresler BA (eds) Computer modelling in ocean engineering. Balkema, Rotterdam, p 87-94

Moloney CL, Bergh MO (1986) The effect of sedimentation and microbial nitrogen regeneration in a plankton community. A simulation investigation. J Plankton Res $8(3)$ : $427-445$

Monbet Y, Bassoullet P (1989) Bilan des connaissances océanographiques en rade de Brest. Rapport CEA/IPSN, code DERO/EL 89-23, IFREMER, Plouzané

O'Neill RV, De Angelis DL, Pastor JJ, Jackson NBJ, Post WM (1989) Multiple nutrient limitations in ecological models. Ecol Model 46:147-163

O'Viatt CA, Doering PH, Nowicki BL, Zoppini A (1993) Net system production in coastal waters as a function of eutrophication, seasonality and benthic macrofaunal abundance. Estuaries 16(2):247-254

Paasche E (1973) Silicon and the ecology of marine plankton diatoms. II Silicate uptake kinetics in five diatoms species. Mar Biol 19:262-269

Peeters JCH, Joordens JCA, Smaal AC, Nienhuis PH (1993) The impact of marine eutrophication on phytoplankton and benthic suspension feeders: results of a mesocosm pilot study. Report DGW 930039, NIOO/CEMO-654, Yerseke

Peterson DH, Festa JF (1984) Numerical simulation of phytoplankton productivity in partially mixed estuaries. Estuar Coast Shelf Sci 19:563-589

Prieur L, Sathyendranath S (1981) An optical classification of coastal and oceanic waters based on the specific spectral absorption curves of phytoplankton pigments, dissolved organic matter, and other particulate materials. Limnol Oceanogr 26(4):671-689

Quéguiner B, Tréguer P (1984) Studies on the phytoplankton in the Bay of Brest (Western Europe). Seasonal variations in composition, biomass and production in relation to hydrological and chemical features (1981-1982). Bot Mar $27: 449-459$

Radach G, Moll A. (1993) Estimation of the variability of pro-

Editorial responsibility: Otto Kinne (Editor),

Oldendorf/Luhe, Germany duction by simulating annual cycles of phytoplankton in the central North Sea. Prog Oceanogr 31:339-419

Raglieneau $O$, De Blas-Varela E, Tréguer P, Quéguiner B, Del Amo Y (1994) Phytoplankton dynamics in relation to the biogeochemical cycle of silicon in a coastal ecosystem of western Europe. Mar Ecol Prog Ser 106:157-172

Redf:eld AC (1934) On the proportions of organic derivatives in sea water and their relations to the composition of plankton. James Johnstone Memorial Volume. Univ of Liverpool, p 176-192

Rosenberg R (1991) Eutrophication-related marine ecosystem studies in western Sweden. In: Colombo G, Ferrarí l, Ceccherelli VU, Rossi R (eds) Marine eutrophication and population dynamics. Olsen \& Olsen, Fredensborg, p 17-20

Ross AH, Gurney SC, Health MR (1994) A comparative study of the ecosystem dynamics of four fjords. Limnol Oceanogr $39(2): 318-343$

Salomon JC, Breton M (1991) Numerical study of the dispersive capacity of the Bay of Brest, France, towards dissolved substances. In: Lee JMW, Cheung YK (eds) Environmental hydraulics. Balkema, Rotterdam, p 459-464

Shumway SE (1990) A review of the effects of algal blooms on shellfish and aquaculture. J World Aquacult Soc 21: $65-105$

Smaal AC, Peeters JCH, Haas HA, Heip CHR (1994) The impact of marine eutrophication on phytoplankton and benthic suspension feeders. Progress report RIKZ 94035، NIOO/CEMO, Yerseke

Smayda TJ (1990) Novel and nuisance phytoplankton blooms ir the sea: evidence for a global epidemic. In: Granéli E (ed) Toxic marine phytoplankton. Elsevier Science Publishing Co, New York, p 29-40

Steele JH (1962) Environmental control of photosynthesis in the sea. Limnol Oceanogr 7(2):137-150

Steele JH, Henderson EW (1992) The role of predation in p.ankton models. J Plankton Res 14(1):157-172

Van der Molen DT (1991) A simple dynamic model for the simulation of phosphorus from sediments in shallow eutrophic systems. Water Res 25(6):737-744

Vilicic D, Legovic T, Zutic V (1989) Vertical distribution of paytoplankton in a stratified estuary. Aquat Sci 51(1): $31-46$

Wiegert RG, Christian RR, Wetzel RL (1981) A model view of the marsh. In: Pomeroy LR, Wiegert RG (eds) The ecology of salt marsh Springer Verlag, New York, p 183-218

Submitted: March 9, 1998; Accepted: April 30, 1999

Proofs received from author(s): November 12, 1999 